\title{
Local Wisdom Values-Based Coastal Natural Resources Management
}

\author{
Cahyowati Cahyowati, Galang Asmara, Arba Arba, Akhmad Zainuri \\ Doctoral Program of Law \\ University of Mataram \\ Lombok, Indonesia \\ a.cahyowati@gmail.com
}

\begin{abstract}
The objective of this papers to describe the principles underlying coastal natural resources management, the norms and sanctions for their violations; to review and criticize legislation and policies related to regulation of coastal natural resources management, including Awig-awig in Pujut Subdistrict, Central Lombok regency, Indonesia. We used socio legal research types and focus group discussion with 20 respondents to establish the projects. The results indicated that coastal natural resources management is based on nine legal principles including principles of Benefit, Sustainability, Accessibility, Consensus, Protection/Environmental Arrangement, Common Interest, Supreme Awig-Awig, Legal Sync and Institution. The Jam, Local Implementing Authority (Awig-Awig) applies eleven principles: Local, Pancasila, Prioritizing Local Habits, Responsibility, Electing and Being Elected, Freedom of Argument, Compliance with Laws and Collective Agreements, Upholding Dignity of the Institute, Independence, Being Tiered, and Deliberation Priority principles. The norms in the of coastal natural resources management include norms of command, prohibition, and permissibility, and sanctions for violations in the form of dismiss on activities, and environmental restoration fines imposed. In conclusion, Awig-awig management of natural resources in Pujut Sub-district, Central Lombok Regency, does not conform to the principles in several related government laws.
\end{abstract}

Keywords - coastal natural resource management; local wisdom; legal principles; awig-awig

\section{INTRODUCTION}

Coastal natural resources have great potential to be developed. Therefore, the customary society in the region should plays crucial role in the management of coastal natural resources, namely the requirement to maintain it regularly and sustainably to improve the welfare of the community. Utilization of coastal natural resources can be realized by protecting the values of local wisdom, since such action can provide guarantee to the existence of natural resources to be relished by the next generations. Local Wisdom itself refers to applicable noble values to the community life, among others, to help protect and manage a promising environment sustainability. Local wisdom in the management of coastal natural resources is essentially a process of controlling the actions of human around the coastal areas so that the utilization of natural resources can be performed wisely by heeding the rules of environmental sustainability [1]
Marine potentials management by indigenous community in every coastal area is generally carried out through traditional custom guidelines, which is known as marine customary rights. Compared with the ulayat right to land, the authority, which, according to customary law, is owned by the customary law community over a particular area which is the environment of its citizens, where it permits the public to benefit from natural resources, including land, in the territory for its survival, it appears that customary rights over the sea as a tradition that has been held for generations and respected, has not been fully recognized by both the government and the entrepreneurs, especially those concerning customary rights over the coast and oceans. There are several marking elements for the existence of coastal areas of coastal Customary communities [2], including:

- There is an area of the sea where local people can attain their living necessities.

- The ability to reach those places in question.

- Performed from generation to gene ration.

- Performed periodically.

- Must be sustainably retained from other parties entering the territory without the permission of the indigenous community.

The real control over territories by indigenous society is closely linked to the relationships built to meet its needs over the region and generally it is something hereditary from the ancestors. In the de yure view, it is actually the authority of indigenous communities. The authority herein is concerned with the management and utilization of natural resources according to the principles of customary law with their own peculiarities. Historically existed awig-awig in Lombok is unwritten (non-sriptum juice) but some have been written (scriptum juice), and have even been transformed in the form of Village Rules. This indicates that awig-awig in its genuine form also experiences dynamics integrated into the system of positive law proceedings.

Research related to coastal natural resources based on local wisdom has been done in Situbondo Regency. The results of this previous study indicate that the local wisdom of sea pruning, which is in the form of gathering events that are held every year, aimed at feeding the fish accompanied by praying 
together for the sustainability of the fishery in the sea is maintained. This is done by the local people by prayer as a process to get barokah from the Kyai, because by the local community it is believed that with baroque, all activities and problems easily and smoothly resolvable. The tradition of Tellasan (feast) to the community is done on the 27 th or $\mathrm{H}-3$ days, three days before the feast of the sea, has been abandoned, so that the time for the marine biota exploited in the capture to breed and regenerate so that the quantity and its quality can be well preserved and sustained [3]. In a study conducted by IPB on awig-awig entitled "Kearifan Lokal pada Laut di Provinsi Nusa Tenggara Barat di Kecamatan Tanjung Kabupaten Lombok Barat dan di Dusun Serewe Kabupaten Lombok Timur" the concept of local wisdom forming a ban on the use of bombs and potassium cyanide on coral reef area found. This rule is aimed at the fishermen so that the efforts made to catch the fish do not damage the existing ecosystem and signifies the ban on cutting down mangrove forests because of its function for the community as a place of life cycle of fish such as shrimp and crab. In addition, mangrove serves as a barrier of sea abrasion [4].

In addition, the forms of protection from local wisdom and customs in Mukim Mane are; the existence of uroe pantang laoti; not using fishing gear that is harmful to the environment; take care of fellow fishermen at sea; Khanduri laot; not taking fish in the rumpon belonging to other fishermen; pay attention to keunenong; guarding coral reefs by not using dangerous fishing gear; guarding mangroves by not cutting haphazardly; and maintain the cleanliness of the beach by not disposing garbage and ship repaired materials [5].

In line with the realization of protection based on local wisdom in Mukim Mane, the form of local wisdom of the people in the coast of Teluk Cendrawasih National Park, among others: catching fish using traditional tools (fishing rods, fish traps, balobe etc.), catching time not every day, (months, stars and wind direction), feeling adequate when all their daily needs are met, prohibiting the taking of a biota or tree within a certain time (now known as sasi), not capturing in too much quantity (taboo if there are dead fish caught for disposal to sea), harvesting the harvested size (generally large size), not telling others the location of the capture (this is done so that few people utilize natural resources in the same location) divide the catch to his relatives if the catch is quite a lot, there are some of the sacred sites (forbidding in) this may provide an opportunity for some biota to breed in it, the belief of an ancestor derived from one of the biota in the sea and in the forest [6].

The evidence of the same form of local wisdom described above also lies in Lembata Regency of East Nusa Tenggara, where the established provisions as the realization of local wisdom in coastal natural resource management include: Leffa Nuang (season of descending to the sea) preceded by prayer, conducted annually, usually in May to October, Poan Kemer Puru Larang (tradition of customary prohibition for the community not to take the sea products freely, Badu-when allowed to catch that Based on conservation, and Muro-ban which is accompanied by sanctions and fines. Tradition and wisdom has a very strategic role in the management of coastal and marine resources. Ground the above described previous related resulted to the recent study, it can be seen that their focuses lie on the local wisdom in the management of coastal natural resources, while this paper examines the principles underlying the management of coastal natural resources in local rules (Awig-awig), the form of norms and sanctions for violations in Pujut Sub-district, Central Lombok District,

\section{METHOD}

This study employs socio-legal research method, legal research that represents the interrelationships between the contexts in which the law exists [7]. The law as the object of study is not assumed to be given or taken for granted, but analyzed problematically by diagnosing extrapolative field finding data. This research was conducted in Mertak Village Pujut Sub District, Central Lombok Regency. The data of this study, in the form of legal materials, are collected by documentation techniques, by reviewing and critiquing legislation on coastal natural resource management, including Awig-awig, while primary data collection is conducted through focus group discussions on 20 people consisting of figures communities, religious leaders, fishermen, youth and local village staff. Analysis of legal materials and data obtained is done by qualitative content analysis method.

\section{RESULT AND DISCUSSION}

\section{A. Principles Underlying the Coastal Natural Resources Management in Pujut Sub-District, Central Lombok District}

Underlying principles for coastal natural resources management in Pujut Sub-district, Central Lombok regency are Awig-awig (law applicable in the life order of Sasat people in Lombok Island). From the results of the assessment of Awigawig it is found that there are 9 legal principles namely: Benefit Principles, Sustainability Principles, accessibility Principles, Consensus Principles, Principles of Protection/Environmental Arrangement, Common Interest Principles, Supreme AwigAwig Principle, Principles of Legal Sync, and Institutional Principles. These principles can be specified in detail in Table 1.

TABLE I. PRINCIPLES FOR COASTAL NATURAL RESOURCES MANAGEMENT in PuJUt Sub-District, CENTRAL LOMBOK REGENCY [8]

\begin{tabular}{|l|l|l|}
\hline No & \multicolumn{1}{|c|}{ Principles } & \multicolumn{1}{|c|}{ Article } \\
\hline 1. & Beneficial Principles & $\begin{array}{l}\text { Article 2; Article 3 (1); Article 4 paragraph } \\
\text { (1); Article 4 paragraph (4); Article 5 } \\
\text { paragraph (1); Article 7 paragraph (2) }\end{array}$ \\
\hline 2. & Sustainability Principles & $\begin{array}{l}\text { Article 3; Article 4 paragraphs (1) and (2) } \\
\text { Article 5 paragraph (1); Article 6 paragraph (1) } \\
\text { and paragraph (2); Article 7 paragraph (1) }\end{array}$ \\
\hline 3. & Accessibility Principles & Article 2 paragraph (5); Article 5 paragraph (1) \\
\hline 4. & Deliberation Principles & $\begin{array}{l}\text { Article 2 paragraph (6); Article 3 paragraph } \\
\text { (4); Article 5 paragraph (1) }\end{array}$ \\
\hline 5. & $\begin{array}{l}\text { Principles of Protection/ } \\
\text { Environmental Arrangement }\end{array}$ & $\begin{array}{l}\text { Article 2 paragraph (7); Article 3 paragraph } \\
\text { (1), (2), (3), (5); Article 6 paragraph (1) }\end{array}$ \\
\hline 6. & Principles of Public Interest & Article 4 paragraph (2); and (4) \\
\hline 7. & $\begin{array}{l}\text { Principles of Supreme of } \\
\text { Awig-awig }\end{array}$ & Article 5 paragraph (2) \\
\hline 8. & Principles of Legal Sync & Article 5 paragraph (3) \\
\hline 9. & $\begin{array}{l}\text { Principles } \\
\text { Institutionalization }\end{array}$ & $\begin{array}{l}\text { Article 8; Article 9 paragraph (1), paragraph } \\
\text { (2); Article 10 paragraph (1); Article 11; and } \\
\text { Article 12 }\end{array}$ \\
\hline
\end{tabular}


Principles to the Awig-awig Executing Agency in the Management of Coastal Natural Resources in Pujut Subdistrict, Central Lombok Regency are also conducted on the draft of Awig-awig. In the study found there are 11 principles covering the Principles of Lokalitet, Principles of Pancasila, Principles of Prioritizing Local Habits, Principles of Responsibility, Principles of Selection and Selection, Principles of Freedom of Argument, Principles of Obedience Against Laws and Collective Agreements, Principle of Harkat and Dignity of Institutions, Tiered Principles, and Priority Principles of Deliberation. The principles are presented in detail in Table 2.

TABLE II. PRINCIPLES AND ARTICle PlaCe of DisPosal FOR AWIGAwig ExECUTING AgENCY IN THE COASTAL NATURAL RESOURCES Management in Pujut Sub-District, Central LOMBOK REgEnCy [8]

\begin{tabular}{|l|l|l|}
\hline No. & \multicolumn{1}{|c|}{ Principles } & \multicolumn{1}{|c|}{ Article } \\
\hline 1. & Local Principles & Article 2 and 3 \\
\hline 2. & Principles of Pancasila & Article 4 \\
\hline 3. & $\begin{array}{l}\text { Principles of Local Community } \\
\text { Habitualization }\end{array}$ & Article 5 \\
\hline 4. & Responsibility Principles & Article 6 \\
\hline 5. & Election Principles & Article 8 \\
\hline 6. & Freedom of Speech Principles & Article 8 \\
\hline 7. & $\begin{array}{l}\text { Principles of Obedience Against Laws and } \\
\text { Collective Agreements }\end{array}$ & Article 9 \\
\hline 8. & $\begin{array}{l}\text { Principles of Upholding the Harkat and } \\
\text { Dignity of the Institute }\end{array}$ & $\begin{array}{l}\text { Pa Article sal } \\
\text { pragraph (2) }\end{array}$ \\
\hline 9. & Independence Principles & Article 11 \\
\hline 10. & Tierred Princples & Article 13 \\
\hline 11. & Prioritizing Deliberation Principles & Article 15 \\
\hline
\end{tabular}

Source: Awig-awig in Teluk Bumbang Area Management 2013

If the principles in table 1 and 2 are carefully observed, both the principles relating to the Coastal Natural Resource Management, as well as the principles associated with the Awig-awig Executing Agency, show that there are differences between the principles contained in various laws and regulations in Law No. 32 of 2009 on Environmental Protection and Management [9]. The principles contained in the law referred to are listed in Article 2, as follows:

TABLE III. COMPARISON BETWEEN PRINCIPLES IN $A W I G-A W I G$ WITH THE LAW ON ENVIRONMENTAL MANAGEMENT

\begin{tabular}{|l|l|}
\hline \multicolumn{1}{|c|}{ The principles in Awig-awig } & \multicolumn{1}{|c|}{$\begin{array}{c}\text { The principles in Law on } \\
\text { Environmental Management }\end{array}$} \\
\hline - Beneficial Principles & - state responsibility; \\
- Sustainability Principle & - sustainability and sustainability; \\
- Aksebilitas Principle & - harmony and balance; \\
- The principle of Deliberation & - alignment; \\
- Principles of Protection / & - benefits; \\
- Environmental Arrangement & - caution; \\
- Joint Interest Principle & - justice; \\
- The Supreme Principle Awig- & - eco-region; \\
- Principle of Legal Sync & - biodiversity; \\
- Institutionalization & - polluters paying; \\
& - participatory; \\
& - Local wisdom; \\
& - regional autonomy \\
\hline
\end{tabular}

Source: Processed Primary Legal Material

In accordance with principles comparison illustrated in Table 3, distinction in the principles contained in Law no. 27 of
2007 on the Management of Coastal Areas and Small Islands is also found [10]. These principles are contained in Article 3. Furthermore, the comparison of environmental protection principles contained in Awig-awig and Law no. 27 of 2007 on the Management of Coastal Zone and Small Islands is depicted through Table 4.

TABLE IV. COMPARISON BETWEEN PRINCIPLES IN $A W I G-A W I G$ AND PRINCIPLES IN LAW NO. 27 OF 2007

\begin{tabular}{|l|l|}
\hline The principles in Awig-awig & \multicolumn{2}{|c|}{$\begin{array}{c}\text { The principles in Law no. 27 of } \\
\text { 2007 }\end{array}$} \\
\hline - Beneficial Principles & - Principle of Sustainability; \\
- Sustainability Principle & - Principle of Consistency; \\
- Aksebilitas Principle principle of & - The Principle of Integration; \\
- The Principle of Legal Certainty; \\
Deliberation & - Principle of Partnership; \\
- Principles of Protection / & - Equalization Principles; \\
Environmental Arrangement & - Principles of Community \\
- Joint Interest Principle & - Participation; Openness Principle; \\
- The Supreme Principle & - Decentralization Principles; \\
- Awig-awig Principle of Legal Sync & - Principle of Accountability; and \\
- Institutionalization & - the Principle of Justice \\
\hline
\end{tabular}

Building on the above descriptions, it can be claimed that Awig-awig contains legal-based environmental protection principles that are not the same as those contained in several relevant laws such as Law no. 32 of 2009 on Environmental Protection and Management and Law no. 27 of 2007 on the Management of Coastal Areas and Small Islands. The principles contained in Awig-awig seem to be adapted to the values of life maintained by the local community and the needs of its social life.

\section{B. Norms and Sanctions}

The norms of Awig-awig on Coastal Natural Resource Management in Pujut Sub-district, Central Lombok District consists of 3 forms, namely command, prohibition, and skill. The command norm is formulated with the words "must" and "mandatory". An example of the norm order formulation in Awig-awig is: "must maintain the environment cleanliness", "must participate preserve mangrove forests, sand beaches, and existing stones".

The prohibition norm is formulated with the words "forbidden", and "prohibition". Examples of norms of prohibition in Awig-awig: "ban on entry into a region", "ban on catching protected fish", "banning fishing ban by using bombs, potassium, storm and/other hazardous and toxic materials", "prohibition to buy to buy yield catches using prohibited means "," prohibition to take beach sand, piling up the sea, cutting trees, destroying mangrove trees, rocks and coral. "

The permissible norm is characterized by the word "can", the example of the standard of permissibility in Awig-awig: "fishing can only be done by environmentally friendly fishing gear", "all fish species can be caught by fishermen with the exception of protected fish", "marine aquaculture can be done in a sustainable fishery zone and does not interfere with the voyage ". 
Based on focus group discussion results, the sanctions listed in Awig-awig of Coastal Natural Resource Management in Pujut Sub-district, Lombok center Regency are; activities should be dismissed for carrying out activities in the prohibition area, subject to environmental restoration fines, and subject to customary fine: ngamberayang, and ngurayang. Customary fines ngamberayang is a violation of custom for committing a commendable act that can cause harm to the honor and dignity of others. The sanction is a material that is half the size of a starch fine or by agreement in the deliberations. Customary fines ngurayang is a violation of custom for committing acts that are not commendable that can cause loss of life and material of others. The sanctions are fine of starch, and the catch is taken for the benefit of Awig-Awig Institute.

The process of imposing sanctions against violations of coastal natural resources management norms, including: in case of violations can be reported to the Implementing Agency for Awig-awig start level hamlet, village to sub-district, the report submitted must be accompanied by witnesses and evidence, the decision of sanctions is done in the assembly of bodies according to their level, and the imposition of sanctions shall be granted to the offender if the offender has been found guilty. If a person is suspected of committing an offense but he does not want to acknowledge his actions then his decision is made by working on it.

In the process of law enforcement against violation of norms of coastal natural resources management has not been running as expected because it is related to obstacles encountered, namely: violators who come from outside the region of the region will not be subject to Awig-awig, the number of agencies involved in the management of resources coastal nature resulting in overlapping of authority.

\section{CONCLUSION}

Regulating Awig-awig for the natural resources management in Pujut Sub-district, Central Lombok Regency is not in accordance with the principles contained in several related laws such as Law no. 32 of 2009 on Environmental Protection and Management and Law no. 27 of 2007 on the Management of Coastal Areas and Small Islands. The principles contained in Awig-Awig seem to be adapted to the local community and the needs of the local community. The forms of norms and sanctions against violations of norms of coastal natural resources management are the norms of command, prohibition, and permissibility. The sanction of the norms violation in Awig-awig, is: its activities must be stopped, the environmental restoration fines are imposed, and the customary fines ngamberayang, and ngurayang are also imposed.

\section{ACKNOWLEDGEMENT}

The author would like to thank all the parties who have helped and contributed in the writing of this article, both those who contribute in the form of funding and critical ideas. Hopefully this paper can be useful theoretically and practically for the addition and development of knowledge, especially in the field of legal science.

\section{REFERENCES}

[1] Supriharyono. Pengelolaan Ekosistem Terumbu Karang. Jakarta: Djambatan. 2000.

[2] R. Z. Titaheleu, Hukum Adat Maluku Dalam Konteks Pluralisme Hukum: Implikasi Terhadap Manajemen Sumber Daya Alam Maluku, disampaikan pada pengresmian penerimaan Jabatan Guru Besar Dalam Bidang Ilmu Hukum Mata Kuliah Pengantar Ilmu Hukum dan Ilmu Agraria Pada Fakultas Hukum Universitas Pattimura. 2005.

[3] I. Syahrul. "Local Wisdom of Community Empowerment in the Management and Sustainable Development of Fishery Resources (Study in Situbondo District)." Samakia: Jurnal Ilmu Perikanan 8.1, 2017: 2431.

[4] Santara, A. G., and Rowandi, W. Peran Kearifan Lokal Dalam Pengelolaan Sumberdaya Hayati Kawasan Pesisir dan Laut.

[5] A. W. Perdana, "Pengelolaan Sumberdaya Pesisir Dan Laut Melalui Kearifan Lokal Di Mukim Mane Kecamatan Muara Batu Kabupaten Aceh Utara", Agrisep Vol.7 No.1, 2016.

[6] Feronika Manohas, Mengelola Sumber Daya Alam Menggunakan Kearifan Lokal Masyarakat Pesisir TNTC, 2015.

[7] R. Banakar, Normativity in Legal Sociology Methodological Reflections on Law and Regulation in Late Modernity, Springer International Publishing. 2015.

[8] Awig_Awig Pengelolaan Kawasan Teluk Bumbang di Kecamatan Pujut Kabupaten Lombok Tengah, tahun 2013.

[9] G. Asmara, “Asas-Asas Pengelolaan Sumber Daya Alam Pesisir Berdasarkan Nilai-Nilai Kearifan Lokal di Kecamatan Pujut Kabupaten Lombok Tengah", Laporan Penelitian Program Studi Doktor Ilmu Hukum Universitas Mataram. 2017.

[10] Stefanus Stanis, Pengelolaan Sumberdaya Pesisir Dan Laut Melalui Pemberdayaan Kearifan Lokal Di Kabupaten Lembata Propinsi Nusa Tenggara Timur, Universitas Diponegoro, Semarang, 2005. 